\title{
E-Banking and Monetary Policy in Nigeria
}

\begin{abstract}
By Nathan Audu*
The goal of this paper is to assess the impact of e-banking, which are distinct from conventional banking systems, on central banks' monetary policy. Ebanking poses a challenge to central banks' ability to control interest rates and it may also increase endogenous financial instability. The challenge to interest rate control stems from the possibility that e-banking may diminish the financial system's demand for central bank liability, rendering central banks unable to conduct meaningful open market operations. Increased financial instability could emerge from the increased elasticity of private money production and from the periodic runs out of e-banking into central bank money that generates liquidity crises. Similarly, the future of e-banking is dependent on its growth, regulation and increased technological advancements that would boost the security of the new instrument. It will directly impact the central bank's control of monetary policy unless it is included in its measurements of monetary aggregates. We therefore recommend that since the impact of e-banking on monetary policy depends solely on how fast it will spread and the extent to which it will substitute for cash, it is vital that Central Bank of Nigeria (CBN) considers taking steps to compensate the resulting decrease in its balance sheet. Also, CBN must have to impose special obligations with the money reserve on the e-banking issuer in case of any large increase in e-banking creativity that will affect the monetary policy at the end. The government must keep the rate of prices stable and with this condition, where e-banking will be equal to other forms of money which maintain by apportion percentage as a reserve ratio to the central bank. Similarly, if e-banking spreads moderately, there will be a decrease in the seigniorage income and thus, the decrease in the balance sheet of $C B N$ will be limited. Hence, it must include e-banking in monetary aggregates that the spread of e-banking may lead to a change in the velocity of money.
\end{abstract}

Keywords: monetary policy, e-banking, technology, velocity of money

\section{Introduction}

Following the development of the Internet and the advancements in computer and telecommunications technology, a rising number of financial institutions are introducing and expanding their offerings of electronic banking products (Sciglimpaglia and Ely 2002). These new developments include; mobile banking, internet banking, telephone banking, electronic card, etc., thus the transition from metal currency through paper currency, and now electronic currency, has made transactions more convenient with or without the physical presence of economic agents in a banking hall. The broad acceptance and ease of carrying out transactions using electronic methods has also increased the use of bank card transfers, online

\footnotetext{
*Nigeria Country Economist, West African Monetary Institute, Ghana.
} 
payments and other network-based transactions on a daily basis. The extension of these platforms at the enterprise level has further entrenched its use and changed the purchasing dynamics of economic agents, thus diminishing cash transactions.

Following these developments, modern banks have recognised the need to overhaul their payment service delivery and operations in order to survive and make profit in the 21st century (Opara et al. 2010). The employment of electronic banking (e-banking) and the application of its concepts, techniques, policies, and implementation strategies to banking services has drawn attention and become fundamental to all banks. Its importance has made it a pre-requisite for local and global competitiveness, as it directly affects aspects of banking such as management decisions, and products and services offered by banks, changing the way banks and the corporates relate worldwide and the variation of innovation of service delivery. Customers' avid appetite for fast, effective and efficient banking service has further added to the drive to advance and promote more radical transformation of banking business systems and models, especially in the delivery of cashless banking. Also, the outbreak of the COVID-19 pandemic and its attendant consequences of lockdown, social distancing and hygienic protocol have further exacerbated this.

E-banking has the potential to replace currency in circulation, however it raises a number of policy issues for central banks who are tasked with the responsibility of managing the financial stability of an economy via its policies (monetary) as well as its general interest in payment systems. Thus, extensive research has been done regarding the possible economic effects of e-banking on critical variables such as money supply, currency in circulation, interest rates and business profitability for various countries. While some economists focus on the pure costs and benefits from an economic standpoint, others have focused on the implication on monetary policy and the role of central banks in a cashless society. Some have opined that e-banking will make monetary policy more efficient, while others claim that it would cause central banks to lose their independence, making monetary policy less efficient. This has implications for the way e-banking is viewed worldwide, particularly in developing countries such as Nigeria; an indication that there are a myriad of issues and challenges surrounding the application of e-banking. It has also continued to elicit the reactions of many scholars with, varying and often, conflicting views on the fundamental issues at stake; how they can be resolved; and the importance of such resolution in the everchanging banking system and its regulation.

It is against this backdrop that this paper seeks to assess the impact of ebanking services on monetary policy in Nigeria in a bid to understand its effectiveness and guard against the negative potentials of e-banking on the efficacy of the Central Bank of Nigeria's monetary policy. The major objective of this paper therefore is to evaluate the effectiveness of e-banking services on monetary policy as a major tool for the achievement of economic efficiency and price stability.

It is worthy to note that this paper is different from others in the following ways; (a) the works of Bamidele (2005), focused on the essence of e-banking deployment for monetary policy with a view of advocating necessary actions required for enhancing the effectiveness and efficiency of monetary policy 
implementation in Nigeria, while (b) Imiefoh (2012), evaluated the efficient businesses response to customers demand in Nigeria. The evaluation of these studies revealed that they were both reviews. However, this current study employed both descriptive and inferential statistics to assess the impact of e-banking services on monetary policy in Nigeria.

Following the introduction, Section 2 reviews relevant literature while Section 3 discusses the challenges of e-banking for monetary authorities. Section 4 evaluates the methodology and analysis of the estimation and findings. Section 5 concludes with recommendations.

\section{Literature Review}

\section{The Evolution of E-Banking}

The first consumer credit card was issued by the Western Union in 1914, but its root dates back to 1851 when central banks first manipulated book-entries to clear payment balances among themselves through telegraph (David and Glyn 1996). Diners Club issued the first plastic money credit card in 1950, which was accepted by many merchants. This launch by American Express led to a change in the financial landscape in the United States. However, after a year of its inception, nearly hundred banks began to issue their cards. In the United Kingdom, the credit cards was first issued in 1966. Despite all these innovations, the widespread use of electronic banking did not begin until the automated clearing house was set up by the Federal Reserve Bank of the United States in 1972 to provide the US Treasury and commercial banks with an electronic alternative to check processing. Similar systems emerged in Europe around the same time, so electronic banking has been widely used throughout the world on an institutional level for more than three decades. Today, it is used in nearly all of the deposit currencies in the world's banking systems (Wafa 2003, ECB 2000, Rahn 2000). However, Salawu and Salawu (2007) opined that e-banking was first introduced in Nigeria in the late 80s with the Automated Teller Machines (ATMs) at its rudimentary stage, but with a promising future given the size of the country's financial markets and the increased desire to embrace information and communications technology. Nonetheless, in August 2003, the CBN issued guidelines for compulsory practice of e-banking in the country. But, a number of measures were still needed to be put in place to avoid threats to the stability of the entire financial system and the nation's economy (CBN 2004). A survey conducted by CBN in 2002 to determine the level and types of e-banking activities carried out by banks in the country, revealed that 17 banks were offering internet banking, 24 were offering basic telephone, while 13 banks were offering other forms of e-banking. Twelve (12) banks indicated that their websites were hosted in Nigeria, while 22 were hosted outside Nigeria. Fourteen (14) of the websites were for information only, 11 for information transfer systems and 22 for transactional purposes. Furthermore, the survey suggested that 27 banks had security measures on e-banking, while 4 had none. Also, it was observed that 30 banks used authentication as a means of security control, 28 used firewalls, 16 
cryptography, 8 digital signature, 14 digital certificate, 18 used secured socket layer, 15 public key infrastructure and 31 physical security (Audu 2011, CBN 2003). Currently all the twenty-two existing banks in the country are fully compliant with the CBN's guidelines (CBN 2019).

\section{The Impact of E-Banking on Monetary Policy}

In most developing economies such as Nigeria, one of the goals of monetary policy is the promotion of an efficient and sound financial sector. As such, the monetary authorities' avowed objective is to ensure banking soundness and financial sector stability aimed at improving the efficiency of the payments system and the effective transmission of monetary policy to the real sector. Others include ensuring the effective enforcement of market rules to enthrone the right market expectation (CBN 2017a, b). For optimum efficiency of monetary policy, it has to be executed in an atmosphere of financial stability to minimise macroeconomic losses. This means that the expected macroeconomic losses that arose from financial system disturbances should cover the probability of financial disturbance occurrence and the magnitude of macroeconomic costs of such disturbances when they crystalise (Kent et al. 2007, Miller 2000). Considering the link between the real sector and the financial sector of the economy, monetary authorities need to take cognizance of the potential for financial system stability that is vital for the conduct of monetary policy. This conforms to the tasks of monetary authorities' duty of ensuring that shocks from any part of the financial system do not ultimately threaten the health of the system and that of the economy as a whole (Tak 2002).

Also, customers' attitude of the usefulness, easiness and compatibility, is the main driver of consumers' intentions to the adoption of e-banking services. Consumers' perceptions of availability of knowledge, resources and opportunities necessary for using the service, and the pressure of interpersonal and external social contexts toward the use of e-banking are the other two, less important, adoption drivers, as these will reduce the e-banking threat to the financial system (Sandhu and Arora 2020, Giovanis et al. 2019, Foroughi et al. 2019, Singhraul and Garwal 2018). Despite the foregoings, e-banking has improved service-efficiency and cost-efficiency of business. Researchers have observed that different dimensions of customer satisfaction exist, as such both the fiscal and monetary authorities should pursue the digitization of banking, and reforming the security framework to develop trust with a higher acceptance rate amongst the customer (Khan et al. 2021, Pandian and Duraisingh 2021).

Therefore, the effect of any kind of banking transaction or the introduction of new products or services on the system must clearly be evaluated to ensure a healthy financial system (Ovia 2004). The danger arising from the high degree of substitution of currency in circulation with e-money is presented in a decrease in the central bank balance sheet, which hinders the positive influence of the monetary instruments. Also, the new incentives of electronic banking have triggered the basic changes in plan of action measurements like customers' value, market portion, cost structure and revenue sources (Chukwudi and Amah 2018). In order to avoid this negative influence in the near future, there is another possibility to be taken into 
consideration and that is the possibility for the central bank to impose reserve requirements on all issuers of electronic money.

According to previous analyses, the impact of the emergence of electronic money on monetary policy can mostly be expected in the following areas (Al Laham et al. 2009):

a) Decrease in the control of the central bank over money supply: Decreasing the central bank's control of money supply depends on the degree of substitution of currency in circulation with e-money. The currency in circulation is part of monetary aggregates, and if it is decreased as a result of wider use of e-money, it will produce difficulties in measurement of monetary aggregates and of the control of money supply by the central bank. Possible solutions for limitations of this effect are, for example, limitations of the use of e-money. But this will be in direct confrontation with the laws of technological progress and could produce negative external effects on banking in general. Because of that, there is need for intensified research on new opportunities to limit the adverse impacts of replacing cash with electronic money.

b) Increase in the velocity of money: The influence of e-money over monetary policy can be seen through monetary aggregates and the ability of the central bank to control money supply. In the future, impact should be seen through other indicators related to monetary aggregates, like the velocity of money. With the use of e-money, transactions are relatively cheaper which allows increase in the number of transactions, and increase in the speed of money. Generally speaking, it will be useful, but only to the extent that the central bank can control or measure the monetary aggregates.

c) Volatility in exchange rates: The change of the monetary multiplier is an important indicator. This indicator shows the share of currency in the money supply. As a result of e-money, the currency decreases producing effects to multiplier.

d) With the use of e-currency, the need for printing cash is decreasing, which influences the revenues of central banks in terms of seignorage, thereby affecting the balance sheet of the central banks.

e) E-money has a characteristic of easy portability and affordability which offers a wide use in trade among countries. It is assumed that the user of emoney, motivated with the cheaper foreign currency transactions, will prefer the transactions to be in the most powerful currency. So, through PayPal and other services, users from the country with weaker currency will prefer to transfer their money in higher currency. So in this way the dollarisation or euroisation will be a subject to clicking the mouse. Reynolds (2013) posits that this situation can weaken the central bank's control in the process of foreign currency exchange among the countries.

De Grauwe and Costa Storti (2005) argue that central banks and monetary policy will be negatively affected by a transition towards a cashless society. They claim that private institutions issuing money will not be able to control inflation 
and that central banks will lose their independence. They conclude that there will be no mechanism to control price stability if private institutions take on the role to create money. This is due to the problem of price indeterminacy, which can be illustrated by the equation for money market equilibrium, $\mathrm{M}=\mathrm{P}(\mathrm{Y}, \mathrm{r})$. According to this equation, there are infinite number combinations of the money stock, $M$, and price level, $\mathrm{P}$, in which the money market is in equilibrium. Both of these are nominal variables, and assuming that private agents are free of money illusion (implying that they only care about relative prices, and not nominal variables), private agents have no incentive to control the nominal variables $\mathrm{M}$ and $\mathrm{P}$. Today, central banks take on the responsibility to control the money stock in order to prevent inflation. However, in a cashless society central banks will no longer be able to maintain this role of protecting these nominal variables.

However, if a central bank is able to take on a supervisory role in a cashless society and control inflation by granting privately issued money, legal tender characteristics and imposing legal reserve requirements, they could succeed in remaining independent in a cashless society at the same time as controlling inflation. One recent study on the development of a cashless society in Nigeria by Odior and Banuso (2012) predicts monetary policy to become more efficient with less cash in circulation. In 2012, Nigeria implemented the "Cash-Less Nigeria Project" as a part of the goal of being one of the world's top-20 performing economies by 2020 . The policy introduced cash handling charges with the goal to decrease the number of cash payments to prevent revenue leakage, improve efficiency, and reduce transaction costs and the risk for robbery. Studies suggest that implementing a similar cash handling fee in Sweden may better reflect the social cost of cash to make the Swedish payment system more efficient by reducing cash transactions (Moorthy et al. 2020, Bergman et al. 2007, Segendorf and Jansson 2012a, b, Arvidsson et al. 2019), while Martin et al. (2018) opined that a host of cultural and infrastructural issues have created major difficulties in ebanking implementation in Nigeria.

Rather than relying on inflation targeting, Nigeria will place a greater focus on open market operations and reserve requirements (Tolulope and Ajilore 2013, Migap 2011). Moreover, these studies predict that transaction costs will fall in Nigeria as a result of removing the central bank's monopoly in issuing currency, as it allows for competition in the financial sector. In addition, even though seignorage revenues for the central bank will fall, the cost savings from not printing currency will balance this loss. In turn, cashless banking is estimated to increase the velocity of circulation in the long-run which stimulates trade and commercial activities.

Hence, the introduction of e-banking in Nigeria had a salutary impact on monetary policy execution by reducing the non-bank public preference for cash. It is also a useful tool in advancing the integration of the domestic financial system with the international financial architecture. In addition, it serves as a robust payments system that satisfies the needs of economic agents, in areas of timecritical transactions which affects productivity and the overall economic activity. As such, if it is properly deployed, e-banking would enhance public confidence in both payments and financial systems in such a way that monetary policy would be 
transmitted in an unfitted manner. It is in this vein that the $\mathrm{CBN}$ has taken various measures in the banking industry to present them with opportunities to increase the tempo of e-banking in Nigeria, through product diversification of the industry.

\section{The Challenges of E-Banking for Monetary Policy in Nigeria}

The application of Information and Communications Technology (ICT) in the Nigerian banking industry has resulted in improved business performance with positive impact on the domestic economy. In spite of the enormous benefits of electronic banking in promoting economic activity and its ability to promote monetary policy implementation by reducing the size of cash outside banks, it presents a great challenge to operators, regulators and supervisors. Most of these problems arise from its merits that endear it to public banking and the technology employed in its service delivery. Some of these include regulation, surveillance, seigniorage, operational system integrity and legal risk. Other problems faced by developing countries like Nigeria, include obsolescence and inadequate ICT and other infrastructure such as energy, inefficient payments system, information and data security. Bamidele (2005) opined that computers aid information acquisition, while information processing assists banks in providing customer-focused products/services, building beneficial and qualitative long-term relationships with customers, increasing revenue streams, as well as achieving profitability growth in a competitive environment. But, reliance on ICT to provide services could be problematic if requisite systems and infrastructure are either unreliable or unavailable in real-time on a daily basis. Most developing countries such as Nigeria import the required technologies and equipment. Therefore, the issue to contend with borders on the use of updated, secure, state-of-the-art technologies, coupled with the irregularity of power supply, could lead to inefficiencies, such as fraud, delays and breakdown in service delivery that would in turn erode public confidence in the industry, especially where time-critical transactions are involved. He also held that banking business is based on trust and confidentiality which places a fiduciary burden on the banker towards the customer, while security threats to financial information and customer net-worth which could originate from within and/or outside the system is ever-present and heightened in e-banking. This calls for all the regulatory agencies to put in place policies that would ensure standard practices to guarantee data and information confidentiality around-theclock.

Audu (2011) observed that the efficient functioning of e-banking rests entirely on the adequacy of ICT infrastructure in terms of quality, volume and power to ensure its smooth operation. The reverse is the case in Nigeria with loss implication for the operators. When electronic banking transactions are significant in a suboptimal ICT environment, the payments and financial systems could be adversely affected with serious implications for economic activity. Similarly, security breaches and disruption of efficient functioning of e-banking could damage not only a bank's reputation, but also the entire banking system. Hence, the efficacy of monetary policy in ensuring monetary stability rests partly on the assumption of a 
stable velocity of money and the reaction functions of the central bank, and the clearing banks and non-bank public under the classical quantity theory of money. Therefore, the advent of e-banking has changed the financial landscape and increased the potential for cross-border capital movements and capital flight. The implication of this is that the practice of electronic banking could lead to variability of velocity of money in both the short- and medium- term, owing to internet banking, especially where virtually all banks operate within the local economy.

\section{Methodology}

\section{Data Sources, Research Area and Sampling Technique}

The data for this study were obtained through primary and secondary sources. The primary source was through a field survey, while the secondary data were sourced from the CBN Statistical Bulletin and National Bureau of Statistics (NBS). The study covers the entire thirty-six states of Nigeria and the FCT, Abuja. In determining the samplings technique used for this study, we took into consideration the technical nature of the investigation which requires the responses of respondents with a good and related knowledge of the subject matter. To achieve this, a stratified random sampling method was employed for the study. The stratification was to ensure diversification of opinions. Customers and bankers from each state were stratified according to knowledge, and a sample size of 400 respondents was randomly selected from each geopolitical zone. It is hoped that the sample size will be statistically significant for inferential purposes. This method gives a more representative sample in this case than simple random sampling, because in the latter, certain strata may by chance be under- or over- represented in the sample. Hence, the stratified random sampling method guarantees representation of defined groups that are of of particular interest in the sample size. A sample of 2400 was drawn, 400 per zone (stratum).

\section{Instrumentation and Data Collection Procedure}

The measurement instrument for the study is a two-point Likert-type scale questionnaire. The questionnaire was divided into two sections. The first section ' $\mathrm{A}$ ' - dealt with the respondents bio-data, while the second section - ' $\mathrm{B}$ ' contained 27 items into two Likert-type questionnaires to measure the effectiveness of the existing e-banking services in Nigeria.

Both interviews and questionnaires were employed. The interviews were used to supplement the questionnaires. The e-banking survey was administered using the questionnaires, while interviews were used on key players in each zone. To validate survey instruments, 12 questionnaires were pretested on some bank customers and key players in each zone. The instrument was then reviewed and corrected as necessary. Twelve enumerators were recruited and trained to assist in administering the questionnaires on players in the industry. 


\section{Data Analysis Method}

The survey questions were numerically coded and responses stored in computer spreadsheet software, Microsoft Excel Version 2010. The Chi-squares (non-parametric) test and descriptive tables were employed to describe existing relationships between e-banking variables. The formula for Chi-squares is given thus:

$$
\begin{aligned}
& X^{2}=\sum_{i=1}^{n} \frac{\left(O B S_{i}-E X P_{i}\right.}{E X P_{i}} \\
& D F \\
& =(R-1)(C-1)
\end{aligned}
$$

where $X^{2}=$ Chi-Square, $\sum=$ The sum of, $n=$ Total number of observation, $\mathrm{OBS}_{\mathrm{i}}=$ The Observed frequency, $\mathrm{EXP}_{\mathrm{i}}=$ The expected frequency. $\mathrm{DF}=$ Degree of freedom, $\mathrm{R}=$ Total row, $\mathrm{C}=$ Total column

Decision Rule: If the value of $X^{2}$ calculated is greater than the value of $X^{2}$ critical, we reject the Null Hypothesis and accept the Alternative Hypothesis and vice versa.

The data on e-banking and customers were used to capture the impact of ebanking on monetary policy management in Nigeria from the survey data using statistical package for social sciences (SPSS) version 25 software. This would be achieved through the survey questionnaire.

\section{Data and Source}

The paper employed seven key variables; namely, debit card (DEC), internet banking (INTB), monetary base (MB), money supply (M2), mobile payment (MP), money multiplier (m) and velocity of money (v) for the period spanning 2010Q1 to 2020Q4. All the series were sourced from the CBN Statistical Bulletin and the Nigerian National Bureau of Statistics (NBS) data base, respectively.

\section{ARDL Approach}

The Autoregressive Distributed Lag (ARDL) model deals with single cointegration and was introduced originally by Pesaran and Shin (1999) and further extended by Pesaran et al. (2001). The ARDL approach has the merit that does not require all variables to be I(1) as the Johansen framework and it is still applicable if we have $\mathrm{I}(0)$ and $\mathrm{I}(1)$ variables in our set. The bounds test method cointegration has peculiar econometric advantages when compared to other methods of cointegration. These are:

All the variables in the model are assumed to be endogenous. 
The bounds test method for cointegration is being applied irrespectively of the order of integration of the variables. They may be either integrated of the first order or levels [I(1) or I(0)].

$\checkmark$ The short-run and long-run coefficients of the model are estimated simultaneously.

This new approach to co-integration testing that is encompassing irrespective of whether the variables are I(0), I(1) or are mutually co-integrated was developed by Pesaran et al. (2001). The starting point of this test is a data generating process represented by a general VAR of order $\mathrm{z}$ which is rewritten in vector ECM form involving a vector $\sigma$ of variables. They focus on the conditional modeling of the dependent scalar variable $\pi$. Therefore, the vector $\sigma$ is partitioned into the scalar $\pi$ and vector $r$ of dependent variables (under the assumption that there is no feedback from $\pi$ to $r$ ). The model can be written as the following conditional ECM model for $\Delta \pi$ thus:

$$
\begin{aligned}
& \Delta \pi_{t}=\alpha^{\prime} m+\beta_{a} \pi_{t-1}+\beta_{a r} r_{t-1}+\sum_{i=1}^{z-1} \gamma_{i}^{\prime} \Delta \sigma_{t-i}+\vartheta^{\prime} \Delta r_{t}+ \\
& \varepsilon_{t}
\end{aligned}
$$

where $\mathrm{m}$ is a set of deterministic variables like the constant term, trend, seasonal dummies, etc. $\alpha$ is a vector of coefficients of deterministic variables $\varepsilon_{t}$ is the residual term.

To test the absence of a level relationship between $\pi$ and $r$, the approach uses a Wald or F-statistics to test for the joint hypothesis that all coefficients of all (lagged) levels in the ECM equation are zero. Pesaran et al. (2001) x-rays six cases of deterministic ARDL approach to cointegration testing: the application to ebanking to monetary policy components are specified: no intercepts, no trends; restricted intercepts, unrestricted intercepts, restricted trends, unrestricted trends.

The resulting conditional ECMs' may be interpreted as autoregressive distributed models of orders $(\mathrm{z}, \mathrm{z}, \ldots \mathrm{z})$ or ARDL $(\mathrm{z}, \mathrm{z}, \ldots \mathrm{z})$ models. Pesaran et al. (2001) tabulated asymptotic critical value bounds for the F-statistic for all 6 conditional ECM models. If the computed F-statistic from the exclusion of levels in the conditional ECM's falls outside the critical value bounds, the test allows a conclusive inference without needing to know the integration/cointegration status of the underlying variables. But if the F-statistic falls inside the bounds, inference is inconclusive and knowledge of the order of integration of the underlying variables is required before conclusive inferences can be made. If the computed Fstatistic lies below the 5 percent lower bound, the hypothesis that there is no level relationship is accepted at the 5 percent level. If the statistic falls within the 5 percent bounds, the test is inconclusive and when the F-statistic lies above the 5 per cent upper bound, the hypothesis of no level relationship is conclusively rejected.

Also in addition to the F-test, Pesaran et al. (2001), tabulates asymptotic critical value bounds of the t-statistic for testing the significance of the coefficient on the lagged dependent variable in the conditional ECM. Concerning the use of 
the F- and t-statistics, Pesaran et al. (2001) opined the following procedure: test $\mathrm{H}_{0}$ using the bounds procedure based on the Wald or F-statistic. If $\mathrm{H}_{0}$ is not rejected, proceed no further. If $\mathrm{H}_{0}$ is rejected test the coefficient of the lagged dependent variables using the bounds procedure based on the t-statistics. A large value of $t$ confirms the existence of a level relationship between $\pi$ and $\mathrm{r}$.

To test for the existence of a level relationship as in the previous section requires that the coefficients of the lagged changes remain unrestricted. But for the subsequent estimation of the ECM model, a more parsimonious approach is recommended, such as the ARDL approach to the estimation of the level relations discussed in Pesaran and Shin (1999). In practical terms an ARDL (z, z,.. z) model is selected from a broader search analysis, testing the lag orders using information criteria such as AIC or SBC. In this respect, it is interesting that PSS note that the ARDL estimation procedure is directly comparable with the semi parametric Fully Modified OLS approach (FMOLS) of Phillips and Hansen (1990). From the parsimonious ARDL specification, the specification of the estimated levels relationship is then derived, as well as the associated ECM model.

We estimated this basic quarterly e-banking model using the ARDL technique along the lines suggested by Pesaran et al. (2001). The analysis starts from the assumption that the $\mathrm{MS}_{2}$ in e-banking can be modeled by a semi log linear VAR (p) model, augmented with deterministic such as a constant and a time trend. Then using proofs in Pesaran et al (2001) the following conditional ECM was estimated:

$$
\begin{aligned}
& \Delta M S_{2}=\alpha^{\prime} m+\beta_{1} M S_{2 t-1}+\beta_{2 a r} r_{t-1}+\sum_{i=1}^{z-1} \gamma_{i}^{\prime} \Delta \sigma_{t-i}+\vartheta^{\prime} \Delta r_{t}+ \\
& \varepsilon_{t}
\end{aligned}
$$

Before the secondary data were collected from the CBN and were analyzed, key econometric assumptions were considered, and necessary tests were undertaken using EViews 10. A lot of effort was made to get the statistics about e-banking from the inception in Nigeria. The total number of debit card and master card (DEC), internet banking (INTB), point of sales (POS) and mobile payments (MP) from the year 2009 to 2015 as well as gross domestic product (GDP), money supply (M2), money base (MB), $\mathrm{v}$ and $\mathrm{m}$ were adopted on quarterly basis. Even though data on e-banking was available from 2009, we opted for year 2010 due to data consistency emanating from the rebasing of the country's GDP.

\section{Questionnaire Distribution}

The questionnaire response rate of the study is presented in Table 1. An evaluation of the study shows 1,695 respondents representing 70.6 percent response rate returned their completed questionnaire while 705 or 29.3 percent did not. Therefore, for the remainder of this study the 1,695 questionnaires retrieved would constitute the sample size. 
Table 1. Questionnaire Response Rate

\begin{tabular}{|l|c|c|c|c|c|c|c|c|}
\hline Response & $\begin{array}{c}\text { North } \\
\text { Central }\end{array}$ & $\begin{array}{c}\text { North } \\
\text { East }\end{array}$ & $\begin{array}{c}\text { North } \\
\text { West }\end{array}$ & $\begin{array}{c}\text { South } \\
\text { East }\end{array}$ & $\begin{array}{c}\text { South } \\
\text { West }\end{array}$ & $\begin{array}{c}\text { South } \\
\text { South }\end{array}$ & Total & $\%$ \\
\hline Retrieved & 250 & 300 & 245 & 300 & 300 & 300 & 1695 & 70.6 \\
\hline $\begin{array}{l}\text { Not } \\
\text { Retrieved }\end{array}$ & 150 & 100 & 155 & 100 & 100 & 100 & 705 & 29.3 \\
\hline Total & $\mathbf{4 0 0}$ & $\mathbf{4 0 0}$ & $\mathbf{4 0 0}$ & $\mathbf{4 0 0}$ & $\mathbf{4 0 0}$ & $\mathbf{4 0 0}$ & $\mathbf{2 4 0 0}$ & $\mathbf{1 0 0}$ \\
\hline
\end{tabular}

Source: Field Survey 2020.

\section{Gender Composition of Sample}

Table 2 is a representation of gender composition of respondents in Section A. Respondents in the male category represents 745 (44\%), while respondents who are female constitute $950(56 \%)$. Since it is our intention to analyze the data based on the six geo-political zones, the implication of the marginal difference between the six zones in terms of their responses to any question of importance would be highlighted in the analysis.

There was no intention to compare responses of each question of importance that relates to this study with the gender of our respondents. Even though Table 2 reveals a marginal difference between the genders, it has no implication on the result of the study. More so, no attempt was made to draw equal number of respondents from both sexes - male and female.

Table 2. Distribution of Respondents by Sex

\begin{tabular}{|l|c|c|c|c|c|c|c|c|}
\hline Sex & $\begin{array}{c}\text { North } \\
\text { Central }\end{array}$ & $\begin{array}{c}\text { North } \\
\text { East }\end{array}$ & $\begin{array}{c}\text { North } \\
\text { West }\end{array}$ & $\begin{array}{c}\text { South } \\
\text { East }\end{array}$ & $\begin{array}{c}\text { South } \\
\text { West }\end{array}$ & $\begin{array}{c}\text { South } \\
\text { South }\end{array}$ & Total & $\%$ \\
\hline Male & 140 & 150 & 120 & 115 & 100 & 120 & 745 & 44 \\
\hline Female & 110 & 150 & 125 & 185 & 200 & 180 & 950 & 56 \\
\hline Total & $\mathbf{2 5 0}$ & $\mathbf{3 0 0}$ & $\mathbf{2 4 5}$ & $\mathbf{3 0 0}$ & $\mathbf{3 0 0}$ & $\mathbf{3 0 0}$ & $\mathbf{1 6 9 5}$ & $\mathbf{1 0 0}$ \\
\hline
\end{tabular}

Source: Field Survey 2020.

\section{Age Composition of Sample}

The pattern of responses as x-rayed in Table 2, indicates that 300 and 400 respondents representing $13 \%$ and $21 \%$ respectively are within $21-30$ and $31-40$ age bracket. The result also reveals that 800 and 660 respondents fall within the 41-50 and above 51 age brackets representing 36\% and $29 \%$ respectively of the sample. We assume that most of the experienced bankers and seasoned customers would be found among this age bracket. It is vital to note that we do not intend to relate one's age with any question of importance in the research instrument, thus, no attempt was made to draw equal number of respondents from each age bracket. 


\section{Composition of Respondents by Qualification}

Table 3. Distribution of Respondents by Qualification

\begin{tabular}{|l|c|c|c|c|c|c|c|c|}
\hline Qualification & $\begin{array}{c}\text { South } \\
\text { East }\end{array}$ & $\begin{array}{c}\text { South } \\
\text { West }\end{array}$ & $\begin{array}{c}\text { South } \\
\text { South }\end{array}$ & $\begin{array}{c}\text { North } \\
\text { Central }\end{array}$ & $\begin{array}{c}\text { North } \\
\text { East }\end{array}$ & $\begin{array}{c}\text { North } \\
\text { West }\end{array}$ & Total & $\%$ \\
\hline SSCE/GCE/NCE/DIP. & 100 & 97 & 78 & 73 & 75 & 60 & 483 & 28.50 \\
\hline B.Sc./BA/B.Ed/HND & 100 & 90 & 42 & 80 & 100 & 65 & 477 & 28.14 \\
\hline MSc/MA/MEd/MBA & 100 & 115 & 162 & 130 & 92 & 90 & 689 & 30.97 \\
\hline Ph.D. & 45 & 53 & 80 & 17 & 25 & 30 & 250 & 12.37 \\
\hline Total & $\mathbf{3 0 0}$ & $\mathbf{3 0 0}$ & $\mathbf{3 0 0}$ & $\mathbf{2 5 0}$ & $\mathbf{3 0 0}$ & $\mathbf{2 4 5}$ & $\mathbf{1 6 9 5}$ & $\mathbf{1 0 0}$ \\
\hline
\end{tabular}

Source: Field Survey 2020

From Table 3, $473(21 \%)$ were holders of either SSCE or GCE or NCE or diploma certificates, 828 (37) of the sample were first degree holders while 698 (31\%) of the total respondents were holders of a Master's degree. Only 250 (11\%) of the sample are holders of Ph.D degrees. The degree holders include those whom obtained certificates in Banking and Finance, Insurance, Accounting, Business Administration and related disciplines.

Analysis of E-Banking Efficiency Rating

Table 4. Respondents' Rating of E-Banking Efficiency in Nigeria

\begin{tabular}{|l|c|c|c|c|c|c|c|c|}
\hline Responses & $\begin{array}{c}\text { South } \\
\text { East }\end{array}$ & $\begin{array}{c}\text { South } \\
\text { West }\end{array}$ & $\begin{array}{c}\text { South } \\
\text { South }\end{array}$ & $\begin{array}{c}\text { North } \\
\text { Central }\end{array}$ & $\begin{array}{c}\text { North } \\
\text { East }\end{array}$ & $\begin{array}{c}\text { North } \\
\text { West }\end{array}$ & Total & \% \\
\hline Efficient & 157 & 186 & 90 & 150 & 186 & 187 & 956 & 56.4 \\
\hline Average & 61 & 76 & 132 & 89 & 94 & 41 & 493 & 29.1 \\
\hline Insufficient & 82 & 38 & 78 & 11 & 20 & 17 & 246 & 14.5 \\
\hline Total & $\mathbf{3 0 0}$ & $\mathbf{3 0 0}$ & $\mathbf{3 0 0}$ & $\mathbf{2 5 0}$ & $\mathbf{3 0 0}$ & $\mathbf{2 4 5}$ & $\mathbf{1 6 9 5}$ & $\mathbf{1 0 0}$ \\
\hline
\end{tabular}

Source: Field Survey 2020.

Table 4 analyses respondents rating of e-banking in Nigeria. The result reveals that 956 respondents representing 56.4 per cent are of the opinion that e-banking is efficient, $493(29.1 \%)$ believed it is average while $246(14.5 \%)$ respondents says it is inefficient. The implication of the result in Table 4 is that e-banking has made life easier for the people in the six geo-political zones.

Table 5. Comparative Exploration between E-Banking and Conventional (Why do you Prefer E-Banking to Conventional Banking?)

\begin{tabular}{|l|c|c|c|c|c|c|c|c|}
\hline Responses & $\begin{array}{c}\text { South } \\
\text { East }\end{array}$ & $\begin{array}{c}\text { South } \\
\text { West }\end{array}$ & $\begin{array}{c}\text { South } \\
\text { South }\end{array}$ & $\begin{array}{c}\text { North } \\
\text { Central }\end{array}$ & $\begin{array}{c}\text { North } \\
\text { East }\end{array}$ & $\begin{array}{c}\text { North } \\
\text { West }\end{array}$ & Total & \% \\
\hline Safe & 95 & 57 & 95 & 155 & 187 & 40 & 629 & 37.1 \\
\hline Time saving & 57 & 105 & 57 & 29 & 41 & 145 & 434 & 25.6 \\
\hline Convinient & 100 & 93 & 100 & 46 & 48 & 21 & 408 & 24.1 \\
\hline Efficient & 48 & 45 & 48 & 20 & 24 & 39 & 224 & 13.2 \\
\hline Total & $\mathbf{3 0 0}$ & $\mathbf{3 0 0}$ & $\mathbf{3 0 0}$ & $\mathbf{2 5 0}$ & $\mathbf{3 0 0}$ & $\mathbf{2 4 5}$ & $\mathbf{1 6 9 5}$ & $\mathbf{1 0 0}$ \\
\hline
\end{tabular}

Source: Field Survey 2020.

The respondents' preference for e-banking in Nigeria is presented in Table 5. The assessment of respondents' views reveals that 629 or 37.1 percent of the 
respondents are of the view that they prefer e-banking to conventional banking because it is safe; $434(25.6 \%)$ held that they prefer e-banking to conventional banking because it is time-saving; while 408 or $24.1 \%$ and $224(13.2 \%)$ held that they prefer e-banking to conventional banking because it is convenient and efficient, respectively. The implication of their responses in Table 5 is that the emanation of e-banking makes life more conducive in terms of business and financial transactions in the six geo-political zones.

Investigation of the Positive Impact of E-Banking on Monetary Policy

Table 6. Does E-banking have any Positive Impact on Monetary Policy

\begin{tabular}{|l|c|c|c|c|c|c|c|c|}
\hline Responses & $\begin{array}{c}\text { South } \\
\text { East }\end{array}$ & $\begin{array}{c}\text { South } \\
\text { West }\end{array}$ & $\begin{array}{c}\text { South } \\
\text { South }\end{array}$ & $\begin{array}{c}\text { North } \\
\text { Central }\end{array}$ & $\begin{array}{c}\text { North } \\
\text { East }\end{array}$ & $\begin{array}{c}\text { North } \\
\text { West }\end{array}$ & Total & \% \\
\hline Yes & 223 & 150 & 211 & 198 & 167 & 100 & 1049 & 61.9 \\
\hline No & 77 & 150 & 89 & 52 & 133 & 145 & 646 & 38.1 \\
\hline Total & $\mathbf{3 0 0}$ & $\mathbf{3 0 0}$ & $\mathbf{3 0 0}$ & $\mathbf{2 5 0}$ & $\mathbf{3 0 0}$ & $\mathbf{2 4 5}$ & $\mathbf{1 6 9 5}$ & $\mathbf{1 0 0}$ \\
\hline
\end{tabular}

Source: Field Survey 2020.

Table 6 presents the positive impact of e-banking on monetary policy in Nigeria. 61.9 percent of the respondents believed that e-banking has positive influence on monetary policy, while 38.1 disagreed and held that it does not. Given that majority of the respondents believe in the efficacy of e-banking, monetary authority should take cognizance of this while making policies to improve ebanking policies.

\section{Scrutiny of E-Banking in Nigeria}

Table 7. Rating of E-Banking in Nigeria

\begin{tabular}{|l|c|c|c|c|c|c|c|c|}
\hline Responses & $\begin{array}{c}\text { South } \\
\text { East }\end{array}$ & $\begin{array}{c}\text { South } \\
\text { West }\end{array}$ & $\begin{array}{c}\text { South } \\
\text { South }\end{array}$ & $\begin{array}{c}\text { North } \\
\text { Central }\end{array}$ & $\begin{array}{c}\text { North } \\
\text { East }\end{array}$ & $\begin{array}{c}\text { North } \\
\text { West }\end{array}$ & Total & $\%$ \\
\hline Effective & 157 & 186 & 90 & 150 & 186 & 187 & 956 & 56.4 \\
\hline Average & 61 & 76 & 132 & 89 & 94 & 41 & 493 & 29.1 \\
\hline Ineffective & 82 & 38 & 78 & 11 & 20 & 17 & 246 & 14.5 \\
\hline Total & $\mathbf{3 0 0}$ & $\mathbf{3 0 0}$ & $\mathbf{3 0 0}$ & $\mathbf{2 5 0}$ & $\mathbf{3 0 0}$ & $\mathbf{2 4 5}$ & $\mathbf{1 6 9 5}$ & $\mathbf{1 0 0}$ \\
\hline
\end{tabular}

Source: Field Survey 2020.

Respondents' rating of e-banking is analyzed in Table 7. The rating was categorized into three, thus, effective, average and ineffective, across the six geopolitical zones in Nigeria. 56.4 percent of the respondents rated e-banking in the country as effective; 29.1 percent rated e-banking as average; while 14.5 rated it as ineffective. From the foregoing analysis, it is clear that e-banking has been accepted by the populace; therefore, monetary authority should make policies that will deepen its usage in the country. 


\section{Examination of E-Banking Perception}

Table 8. The Perception of E-Banking in Nigeria

\begin{tabular}{|l|c|c|c|c|c|c|c|c|}
\hline Responses & $\begin{array}{c}\text { South } \\
\text { East }\end{array}$ & $\begin{array}{c}\text { South } \\
\text { West }\end{array}$ & $\begin{array}{c}\text { South } \\
\text { South }\end{array}$ & $\begin{array}{c}\text { North } \\
\text { Central }\end{array}$ & $\begin{array}{c}\text { North } \\
\text { East }\end{array}$ & $\begin{array}{c}\text { North } \\
\text { West }\end{array}$ & Total & \% \\
\hline Very strong & 160 & 122 & 91 & 187 & 145 & 82 & 767 & 46.7 \\
\hline Strong & 45 & 90 & 121 & 35 & 98 & 100 & 469 & 28.6 \\
\hline Weak & 45 & 68 & 63 & 9 & 33 & 43 & 261 & 15.4 \\
\hline Very weak & 50 & 20 & 25 & 19 & 24 & 20 & 158 & 9.3 \\
\hline Total & $\mathbf{3 0 0}$ & $\mathbf{3 0 0}$ & $\mathbf{3 0 0}$ & $\mathbf{2 5 0}$ & $\mathbf{3 0 0}$ & $\mathbf{2 4 5}$ & $\mathbf{1 6 5 5}$ & $\mathbf{1 0 0}$ \\
\hline
\end{tabular}

Source: Field Survey 2020.

The respondents' perception of e-banking in Nigeria is evaluated in Table 8 . The valuation of respondents observation in Table 8, shows that 767 or 47 percent of the respondents believed that e-banking is very strong; $469(29 \%)$ said it is strong; while 261 or $15 \%$ and $158(9 \%)$ perceived e-banking as weak and very weak, respectively. The consequence of these responses in Table 10 is that the introduction of e-banking has made financial transaction for both business and other personal engagement easy for bank customers across the country.

\section{Evaluation of Problems Encountered in E-Banking Usage}

Table 9. Problems Encountered by Bank Customers on the Use of E-Banking

\begin{tabular}{|l|c|c|c|c|c|c|c|c|}
\hline Responses & $\begin{array}{c}\text { South } \\
\text { East }\end{array}$ & $\begin{array}{c}\text { South } \\
\text { West }\end{array}$ & $\begin{array}{c}\text { South } \\
\text { South }\end{array}$ & $\begin{array}{c}\text { North } \\
\text { Central }\end{array}$ & $\begin{array}{c}\text { North } \\
\text { East }\end{array}$ & $\begin{array}{c}\text { North } \\
\text { West }\end{array}$ & Total & \% \\
\hline $\begin{array}{l}\text { Delay in } \\
\text { reverting failed } \\
\text { transaction }\end{array}$ & 70 & 68 & 56 & 75 & 55 & 49 & 373 & 22.0 \\
\hline Fraud & 31 & 56 & 23 & 20 & 36 & 34 & 200 & 11.8 \\
\hline Security issues & 13 & 48 & 50 & 12 & 32 & 15 & 170 & 10.0 \\
\hline User error & 32 & 23 & 35 & 20 & 45 & 30 & 185 & 10.9 \\
\hline Data protection & 23 & 16 & 29 & 21 & 15 & 35 & 139 & 8.2 \\
\hline $\begin{array}{l}\text { Bad internet } \\
\text { connection }\end{array}$ & 36 & 15 & 20 & 14 & 21 & 22 & 128 & 7.6 \\
\hline System error & 55 & 55 & 56 & 67 & 81 & 45 & 359 & 21.2 \\
\hline $\begin{array}{l}\text { Non reversal of } \\
\text { failed } \\
\text { transaction }\end{array}$ & 40 & 19 & 31 & 21 & 15 & 15 & 141 & 8.3 \\
\hline Total & $\mathbf{3 0 0}$ & $\mathbf{3 0 0}$ & $\mathbf{3 0 0}$ & $\mathbf{2 5 0}$ & $\mathbf{3 0 0}$ & $\mathbf{2 4 5}$ & $\mathbf{1 6 9 5}$ & $\mathbf{1 0 0 . 0}$ \\
\hline
\end{tabular}

Source: Field Survey 2020.

The investigation of the problems encountered by bank customers on the use of e-banking is shown in Table 9. The examination of Table 9 indicated that 373 respondents representing 22 percent of the sampled population have experienced long delay in reverting failed transaction; 200 or $11.8 \%$ respondents said they have been defrauded; $10,10.9$ and 8.2 percent representing 170, 185 and 139 respondents, respectively, have problem with security, user error and data protection. Bad internet connection, system error and non-reversal of failed transaction accounting for $7.6,21.2$ and 8.3 per cent, respectively, representing 
128,359 and 141 respondents. The implication of this to monetary authority is that effort must be geared to reducing these identified problems by the customers.

The analysis of the effect of monetary policy on bank customers' choice for ebanking is presented in Table 10. The result reveals that 34.6 percent or 586 respondents believed that monetary policy affect bank customer's choice for ebanking directly, while 65 percent or 1,109 respondents, believed that monetary policy affect bank customer's choice for e-banking indirectly.

Impact of Monetary Policy on Customer's Choice for E-Banking

Table 10. How does Monetary Policy Affect Bank Customer's Choice for E-Banking?

\begin{tabular}{|l|c|c|c|c|c|c|c|c|}
\hline Responses & $\begin{array}{c}\text { South } \\
\text { East }\end{array}$ & $\begin{array}{c}\text { South } \\
\text { West }\end{array}$ & $\begin{array}{c}\text { South } \\
\text { South }\end{array}$ & $\begin{array}{c}\text { North } \\
\text { Central }\end{array}$ & $\begin{array}{c}\text { North } \\
\text { East }\end{array}$ & $\begin{array}{c}\text { North } \\
\text { West }\end{array}$ & Total & $\%$ \\
\hline Directly & 83 & 105 & 108 & 92 & 107 & 91 & 586 & 34.6 \\
\hline Indirectly & 217 & 195 & 192 & 158 & 193 & 154 & 1109 & 65.4 \\
\hline Total & $\mathbf{3 0 0}$ & $\mathbf{3 0 0}$ & $\mathbf{3 0 0}$ & $\mathbf{2 5 0}$ & $\mathbf{3 0 0}$ & $\mathbf{2 4 5}$ & $\mathbf{1 6 9 5}$ & $\mathbf{1 0 0}$ \\
\hline
\end{tabular}

Source: Field Survey 2020.

The implication of the result on e-banking is that monetary policy being the anchor rate serves as a guide to deposit money banks to fix charges on their product, therefore, its impact on customers is indirect.

Chi-square Statistical Analysis for Hypothesis Testing on the Positive Impact of EBanking on Monetary Policy

Table 11. Chi-Square Statistical Analysis for Positive Impact of E-Banking on Monetary Policy Management in Nigeria

\begin{tabular}{|c|c|c|c|c|c|c|c|}
\hline Responses & Bankers & Customers & Cal $x^{2}$ & Critical $x^{2}$ & DF & Total & $\%$ \\
\hline YES & $629(538.4)$ & $420(510.6)$ & \multirow[b]{2}{*}{82.14} & \multirow[b]{2}{*}{3.84} & \multirow[b]{2}{*}{1} & 1049 & 61.9 \\
\hline $\mathrm{NO}$ & $241(331.6)$ & $405(314.4)$ & & & & 646 & 38.1 \\
\hline Total & 870 & 825 & & & & 1695 & 100 \\
\hline
\end{tabular}

Significance level $=0.05$

Source: Field Survey 2020.

The dependent variable in this hypothesis is e-banking, while the independent variable is monetary policy. The statistical analysis used in testing the hypothesis was chi-square statistical analysis. The results of the analysis as presented in Table 11 reveals that the $x^{2}$ - value of 82.14 is greater than the critical $x^{2}$ - value of 3.84 at 0.05 level of significant with 1 degree of freedom. This means that the $x^{2}$-value is statistically significant. This implies that the introduction of e-banking significantly influenced monetary policy management in Nigeria, thus, corroborating Martin et al. (2018), Odior and Banuso (2012), Audu (2011), Salawu and Salawu (2007) findings that e-banking has positive impact on monetary policy. 


\section{KPSS Unit Root Test}

Table 12. KPSS Unit Root Test Result

\begin{tabular}{|l|c|c|c|}
\hline Variables & Levels & $\mathbf{1}^{\text {st }}$ Difference & Decision \\
\hline DEC & 0.425088 & 0.578919 & $\mathrm{I}(0)$ \\
\hline $\mathrm{INTB}$ & 0.254388 & 0.564930 & $\mathrm{I}(1)$ \\
\hline $\mathrm{M}_{2}$ & 0.303304 & 0.578304 & $\mathrm{I}(1)$ \\
\hline $\mathrm{MP}$ & 0.254892 & 0.578668 & $\mathrm{I}(1)$ \\
\hline $\mathrm{MB}$ & 0.254892 & 0.578668 & $\mathrm{I}(1)$ \\
\hline$m$ & 0.043329 & 0.566981 & $\mathrm{I}(1)$ \\
\hline$v$ & 0.191208 & 0.489849 & $\mathrm{I}(0)$ \\
\hline Critical values & & & \\
$1 \%$ & & 0.739000 & \\
$5 \%$ & & 0.463000 & \\
$10 \%$ & & 0.347000 & \\
\hline
\end{tabular}

Note: Kwiatkowski et al. 1992.

Source: Author's computation.

$v\left(\right.$ velocity of money) $=\frac{\mathrm{GDP}}{\mathrm{M}_{2}}, m$ (Money Multiplier $)=\frac{\mathrm{M}_{2}}{\mathrm{MB}}$, DEC $=$ Debit card, $M B=$ Monetary base,

$M_{2}=$ Money supply, GDP $=$ Gross domestic product, INTB = Internet banking, $M P=$ Mobile payments

The econometric analysis of the secondary data of the results of the unit root test without trend of each variable is presented in Table 12. These results suggest that the null hypothesis of stationarity for all variables under consideration cannot be rejected at the 5 percent level of significance. But the results from the KPSS test indicate that apart from DEC and $\mathrm{v}$, which are stationary at levels, all other variables are stationary at first difference at the 5 percent level of significance.

Analysis of Descriptive Statistics on Study Variables

Table 13. Summary Statistics

\begin{tabular}{|l|c|c|c|c|c|c|c|c|}
\hline Description & LM2 & LMB & LDEC & INTB & MP & POS & M & V \\
\hline Mean & 16.453 & 14.920 & 4.994 & 4.204 & 10.931 & 11.455 & 4.846 & 1.290 \\
\hline Median & 16.466 & 14.961 & 5.161 & 3.680 & 4.250 & 6.235 & 4.620 & 1.285 \\
\hline Maximum & 16.765 & 15.625 & 5.837 & 8.120 & 39.820 & 34.860 & 7.160 & 1.450 \\
\hline Minimum & 16.191 & 14.240 & 3.038 & 1.120 & 0.290 & 0.620 & 3.120 & 1.110 \\
\hline Std. Dev. & 0.173 & 0.471 & 0.823 & 2.199 & 12.710 & 11.754 & 1.489 & 0.090 \\
\hline $\begin{array}{l}\text { Coeff. of } \\
\text { Variation }\end{array}$ & 0.011 & 0.032 & 0.165 & 0.523 & 1.163 & 1.026 & 0.307 & 0.070 \\
\hline Skewness & 0.106 & -0.080 & -1.175 & 0.492 & 0.968 & 0.800 & 0.295 & -0.033 \\
\hline Kurtosis & 2.031 & 1.571 & 3.285 & 2.002 & 2.549 & 2.166 & 1.603 & 2.291 \\
\hline Jarque-Bera & 0.902 & 1.895 & 5.139 & 1.800 & 3.626 & 2.984 & 2.109 & 0.465 \\
\hline Probability & 0.637 & 0.388 & 0.077 & 0.407 & 0.163 & 0.225 & 0.348 & 0.792 \\
\hline
\end{tabular}

Source: Author's computation.

Table 13, shows the summary of descriptive statistics of the variables employed to evaluate e-banking in Nigeria. The result reveals evidence of significant variation for five of the variables (DEC, INTB, MP POS and $\mathrm{m}$ ). This is shown by the huge difference between the minimum and the maximum values, 
while that of MB, M2 and v have marginal differences between the minimum and the maximum values over the scope covered.

In terms of the statistical distribution of variables, M2, INTB, MP, POS and $\mathrm{m}$, indicates the evidence of positive skewness implying that the right tail is extreme. In relation to kurtosis which compares the peakedness and tailedness of the probability distribution of a normal distributed series, it shows that all the variables are low peaked and thin tailed (platykurtic) than normal distribution. Similarly, the Jarque-Bera (JB) which uses the information from skewness and kurtosis to test for normality shows the evidence of normality for M2, INTB, MP, POS and $m$ variables.

In addition, MB, DEC and $\mathrm{v}$ have a small and negative skewness statistics (i.e., leptokurtic), suggesting the presence of a left tail. However, the kurtosis statistics of $\mathrm{MB}$ and $\mathrm{v}$ revealed a low peaked and thin tail, while DEC with a kurtosis test statistics of greater than three suggests that the series is moderately peaked and moderately tailed (mesokurtic). Meanwhile, the Jarque-Bera (JB) statistic which measures normality of the distribution using both the skewness and kurtosis statistics show that we cannot reject the null hypothesis for normality for $\mathrm{MB}, \mathrm{DEC}$ and $\mathrm{v}$ variables.

\section{Econometric Evaluation of the Impact of E-Banking on Monetary Policy}

Table 14. The Regression Results of E-Banking on Monetary Variables in Nigeria

\begin{tabular}{|c|c|c|c|}
\hline \multirow[t]{2}{*}{ Explanatory Variables } & \multicolumn{3}{|c|}{$\begin{array}{c}\text { Dependent variables } \\
\text { Parameter [Standard Error] }\end{array}$} \\
\hline & $M S_{2}$ & $m$ & $\boldsymbol{v}$ \\
\hline$c$ & $\begin{array}{c}-4.302321 \\
{[3.050598]}\end{array}$ & $\begin{array}{c}9.713736 \\
{[1.291178]}\end{array}$ & $\begin{array}{c}0.123837 \\
{[0.410674]}\end{array}$ \\
\hline$M S_{2}(-1)$ & $\begin{array}{c}0.141114 \\
{[0.172676]}\end{array}$ & & \\
\hline$m(-1)$ & & $\begin{array}{c}0.104378 \\
{[0.132601]}\end{array}$ & \\
\hline$v(-1)$ & & & $\begin{array}{c}0.683188 \\
{[0258723]}\end{array}$ \\
\hline$M B$ & $\begin{array}{c}0.615473 \\
{[0.150775]}\end{array}$ & & \\
\hline$M B(-1)$ & $\begin{array}{c}0.740527 \\
{[0.161196]}\end{array}$ & & \\
\hline$D E C$ & $\begin{array}{c}-0.222650 \\
{[0.1100150]}\end{array}$ & $\begin{array}{l}-1.483763 \\
{[0.541683]}\end{array}$ & $\begin{array}{r}-0.460546 \\
{[0.170459]}\end{array}$ \\
\hline$M P$ & $\begin{array}{c}0.015633 \\
{[0.004855]}\end{array}$ & $\begin{array}{c}0.070851 \\
{[0.029734]}\end{array}$ & $\begin{array}{c}0.004600 \\
{[0.002148]}\end{array}$ \\
\hline$I N T B$ & $\begin{array}{c}0.032723 \\
{[0.012268]}\end{array}$ & $\begin{array}{c}0.223388 \\
{[0.050645]}\end{array}$ & $\begin{array}{l}-0.065886 \\
{[0.020199]}\end{array}$ \\
\hline$P O S$ & $\begin{array}{r}-0.037017 \\
{[0.008617]}\end{array}$ & $\begin{array}{r}-0.156589 \\
{[0.043073]}\end{array}$ & $\begin{array}{c}0.028587 \\
{[0.012158]}\end{array}$ \\
\hline S.E. of Regression & 0.602171 & 0.424851 & 0.505179 \\
\hline F-statistics & 72.65891 & 88.73931 & 4.796131 \\
\hline Adjusted $\mathrm{R}^{2}$ & 0.951413 & 0.728958 & 0.642623 \\
\hline D.W. statistics & 1.861618 & 2.427820 & 2.151574 \\
\hline
\end{tabular}

Source: Authors' computation using EVIEWS . 
The unit root test in Table 12 shows that the various are a mixture of I (0) and I (1). In view of this, we employed the Autoregressive Distributed lag (ARDL) model for the estimation. The result of the ARDL is presented in Table 14. In order to confirm and validate the statistical properties of the model, we carried out a diagnostics test to ascertain the stability of our model and the results is shown in Table 15. The result of diagnostic tests of: (i) The Breusch-Godfrey LM test (BG) which is the appropriate autocorrelation test when a lagged dependent variable is a regressor, (ii) The Breusch-Pagan-Godfrey (BPG) for Autoregressive Conditional Heteroskedasticity (ARCH) LM test, and (iii) Ramsey's test for specification errors (RESET) (iv) Jarque-Bera test for normality as presented in Table 15 show that our model is stable was conducted to regression:

Table 15. Summary of Diagnostics Result on E-Banking on Monetary in Nigeria

\begin{tabular}{|l|c|c|c|}
\hline Diagnostic Tests & \multicolumn{3}{|c|}{$\begin{array}{c}\text { F-Statistic } \\
\text { (p-values) }\end{array}$} \\
\hline \multirow{2}{*}{ BG LM test } & 2.234404 & 1.075939 & 0.807764 \\
& $(0.2546)$ & $(0.3774)$ & $(0.4791)$ \\
\hline \multirow{2}{*}{ BPG ARCH LM test } & 1.101893 & 0.520830 & 0.940795 \\
& $(0.4965)$ & $(0.8195)$ & $(05318)$ \\
\hline \multirow{2}{*}{ Ramsey Reset test } & 2.069562 & 0.865957 & 0.942355 \\
& $(0.2237)$ & $(0.3720)$ & $(0.624267)$ \\
\hline \multirow{2}{*}{ J-B normality test } & 1.499651 & 2.258945 & 1.423473 \\
& $(0.472449)$ & $(0.323204)$ & $(0.2633)$ \\
\hline
\end{tabular}

Source: Authors' computation using EVIEWS .

\section{Synopsis of Econometric Assessment}

The impact of the various ARDL results and their diagnostic statistics as presented in Tables 14 and 15 are summarized thus:

i. The F-Statistics shows that the three linear models are statistically significant.

ii. The changes in e-banking (DEC) have a positive and significant effect on money supply. This implies that it will affect the liquidity management of the economy. This impact can either be negative or positive based on the position of the central bank;

iii. The increased use of e-banking has a positive and significant effect on money multiplier $(\mathrm{m})$ and income velocity of money $(\mathrm{v})$. This means that the rate of circulation will increase money supply, which will in turn have an implication for money management, either positively or negatively, depending on the central bank's stance.

iv. The results of the diagnostic tests indicate that the three ARDL regressions were well specified.

v. Also, in about two-thirds of the time, the explanatory variables explain the regressand (MS2, $\mathrm{m}$ and $\mathrm{v}$ ) by exactly $60.2,42.5$ and 50.5 percents respectively.

vi. In addition, the goodness of fit $\left(R^{2}\right)$ indicates that the models fit the data well. 


\section{Conclusions}

In the past decade, the sporadic advancement in information technology, coupled with the spread of e-banking, would weaken the Central Bank's control over the supply of bank reserves using the e-banking platform. The Central Bank's role as the monopoly issuer of money will be undermined by the emergence of non-bank competitors in the provision of payment services. As a result, CBN may be reduced to signaling their policy. Also, the future of e-banking is dependent on its growth, and increased technological advancements that would increase the security of this new instrument. In fact, since it has become widely accepted and used in Nigeria, it will directly impact the Central Bank's control of monetary policy, unless the Central Bank includes it in its measurement of monetary aggregates and regulates its growth as well as usage. There is no doubt that, with the spread of electronic trade, the CBN will have to shoulder new responsibilities because of its legal responsibility to monopolize the issuing of money. The most prominent of these responsibilities is: standing up to the results of the universality of e-payment systems and following it up with the development of e-banking products and services.

We therefore recommend that since the impact of e-banking on monetary policy depends solely on how fast it will spread and the extent to which it will substitute for cash, it is vital that $\mathrm{CBN}$ should consider taking steps to compensate the resulting decrease in their balance sheet. Furthermore, CBN must have to impose special obligations with the money reserve on the e-banking issuer in case of any large increase in e-banking activity that would affect the monetary policy at the end. The government, at all levels, must keep the rate of prices stable and with this condition, e-banking will be equal to other forms of money which it maintains by apportioning a percentage as a reserve ratio to the Central Bank. Similarly, if ebanking spreads moderately, the decrease in the seigniorage income and thus the decrease in the balance sheet of CBN will be limited. Hence, it must include ebanking in monetary aggregates that the spread of e-banking may lead to a change in the velocity of money.

\section{References}

Al-Laham M, Abdallat N, Al-Tarawneh H (2009) Development of the electronic money and its impact on the central bank role and monetary policy. Issues in Informing Science and Information Technology 6: 339-349.

Arvidsson N, Jonsson S, Snickare LK (2019) The transaction-relationship paradox. Managerial Finance 45(9): 1253-1271.

Audu NP (2011) The dynamics of e-banking in the South-South region of Nigeria. International Business Management 5(6): 388-397.

Bamidele A (2005) The imperatives of e-banking for monetary policy in Nigeria. $C B N$ Economic and Financial Review 43(1): 65-79.

Bergman M, Guibourg G, Segendorf BL (2007) The costs of paying-private and social costs of cash and card payments. In Riksbank Research Paper Series, 212.

CBN (2002) Survey on electronic-banking in Nigeria. Abuja: CBN Press. 
CBN (2003) Statistical bulletin. Abuja: CBN Press.

CBN (2004) Annual report and statement of account. Abuja: CBN Press.

CBN (2017a) Annual report and statement of account. Abuja: CBN Press.

CBN (2017b) Statistical bulletin. Abuja: CBN Press.

CBN (2019) Statistical bulletin. Abuja: CBN Press.

Chukwudi D, Amah E (2018) Development of e-banking, its benefits and challenges in the Nigerian banking industry. ASPL International Journal of Management Sciences 7(2): 1-7.

David S, Glyn P (1996) A history of money from ancient times to the present day. London: University of Wales Press.

De Grauwe P, Costa Storti C (2005) Is monetary policy in the Eurozone less effective than in the US? CESifo Working Paper No. 1606, November.

ECB (2000) Issues arising from the emerging of electronic money. ECB Monthly Bulletin, November.

Foroughi B, Iranmanesh M, Hyun SS (2019) Understanding the determinants of mobile banking continuance usage intention. Journal of Enterprise Information Management 32(6): 1015-1033.

Giovanis A, Athanasopoulou P, Assimakopoulos C, Sarmaniotis C (2019) Adoption of mobile banking services. International Journal of Bank Marketing 37(5): 165-1189.

Imiefoh P (2012) Towards effective implementation of electronic banking in Nigeria. African Research Review 6(2): 290-300.

Kent C, Ossolinski C, Willard L (2007) The rise of household indebtedness. In C Kent, J Lawson (eds.), The Structure and Resilience of the Financial System, 123-163. Sydney: Reserve Bank of Austria.

Khan F, Chowdhury MSA, Haque A, Akter S, Ahsan SMH (2021) E-banking adoption in Bangladesh; present status and customer satisfaction: an evaluation. Global Journal of Management and Business Research 21(1-A).

Kwiatkowski D, Phillips PCB, Schmidt P, Shin Y (1992) Testing the null hypothesis of stationarity against the alternative of a unit root: how sure are we that economic time series have a unit root? Journal of Econometrics 54(1-3): 159-178.

Martin NC, Igboanugo D, Freeman E, Oddih CS, Sajjad M, Sajjad M (2018) A theoretical Insight on e-banking (internet banking) framework in developing countries. In Proceedings of the International Conference on e-Learning, e-Business, Enterprise Information Systems, and e-Government (EEE), 68-75. The Steering Committee of The World Congress in Computer Science, Computer Engineering and Applied Computing (WorldComp).

Migap JP (2011) Is monetary policy the best instrument for inflation targeting in the Nigerian economy? Journal of Business 3: 34-45.

Miller SM (2000) Monetary policy delegation, contract costs, and contract targets. Working Paper 2000-2001. Connecticut, USA: University of Connecticut.

Moorthy K, Chun T'ing L, Chea Yee K, Wen Huey A, Joe In L, Chyi Feng P, et al. (2020) What drives the adoption of mobile payment? A Malaysian perspective. International Journal of Finance and Economics 25(3): 349-364.

Odior ESO, Banuso FB (2012) Cashless banking in Nigeria: challenges, benefits and policy implications. European Scientific Journal.

Opara CB, Ayopoo O, Darego WM (2010) Analysis of impact of technology on relationship marketing orientation and bank performance. European Journal of Scientific Research 45(3): 291-300.

Ovia J (2004) E-money: instruments and techniques. Paper presented at the $9^{\text {th }} C B N$ Monetary Policy Forum Held at International Conference Centre. Abuja, May $6^{\text {th }}$. 
Pandian SH, Duraisingh V (2021) The cashless society: consumer perception of payment methods. PalArch's Journal of Archaeology of Egypt/Egyptology 18(7): 856-864.

Pesaran MH, Shin Y (1999) An autoregressive distributed lag modelling approach to cointegration analysis. Paper Presented at Econometrics and Economics Theory in the 20th Century: The Ragnar Frisch Centennial Symposium. Cambridge: Cambridge University Press.

Pesaran MH, Shin Y, Smith R (2001) Bounds testing approaches to the analysis of level relationships. Journal of Applied Econometrics 16(3): 289-326.

Phillips PC, Hansen BE (1990) Statistical inference in instrumental variables regression with I (1) processes. The Review of Economic Studies 57(1): 99-125.

Rahn RW (2000) On the future of electronic payments. CATO Congressional Testimony. CATO Institute.

Reynolds G (2013) Electronic money and monetary policy. In Southwestern Economic Proceedings.

Salawu RO, Salawu MK (2007) The emergence of internet banking in Nigeria: an appraisal. Information Technology Journal 6(4): 490-496.

Sandhu S, Arora S (2020) Customers' usage behaviour of e-banking services: interplay of electronic banking and traditional banking. International Journal of Finance \& Economics (Oct).

Sciglimpaglia D, Ely D (2002, January) Internet banking: a customer-centric perspective. In Proceedings of the 35th Annual Hawaii International Conference on System Sciences, 2420-2429.

Segendorf B, Jansson T (2012a) Cards or cash. How should we pay? Sveriges Riksbank Economic Review 3(Oct): 43-57.

Segendorf B, Jansson T (2012b) The cost of consumer payments in Sweden (No. 262). Sveriges Riksbank Working Paper Series.

Singhraul BP, Garwal YS (2018) Cashless economy challenges and opportunities in India. Pacific Business Review International 10(9): 54-63.

Tak S (2002) A study on the effects of the development of e-money on monetary policy in Korea. Economic Papers, Bank of Korea.

Tolulope AO, Ajilore T (2013) Inflation targeting monetary policy rule in Nigeria: estimates of the policy reaction function. International Journal of Economics and Finance 5(7): 139-144.

Wafa ABM (2003) E-money markets: opportunities, threats and horizons. Contemporary Egypt Journal 471/472: 123-145. 